\title{
RISK FACTORS AS A RESULT OF UNHEALTHY NUTRITION IN THE ADULT POPULATION IN SLOVENIA WITH REGARD TO SOCIODEMOGRAPHIC VARIABLES DEJAVNIKI TVEGANJA NEZDRAVEGA NAČINA PREHRANJEVANJA ODRASLIH PREBIVALCEV SLOVENIJE GLEDE NA SOCIODEMOGRAFSKE SPREMENLJIVKE
} Verena Koch', Mojca Gabrijelčič Blenkuš², Matej Gregorič², Stojan Kostanjevec¹

Prispelo: 27. 2. 2013 - Sprejeto: 24. 10. 2013

Original scientific article UDC 613.2:614(497.4)

\begin{abstract}
Introduction: In this research, we carried out an analysis of risk factors due to precarious nutrition among the adult population in Slovenia and correlated the risks with biological and sociodemographic variables.

Methods: Descriptive and quantitative methods were applied. The data were collected by a structured interview on a sample of 1,193 adults from Slovenia. The biological and sociodemographic variables were then correlated with particular risk factors. The data was analysed using a statistical analysis program SPSS.

Results: It was found that only $4.7 \%$ of the population practice healthy nutritional diets, $22.5 \%$ can be considered as acceptable and $62.8 \%$ of the diets were classified as unhealthy. The most frequent risk factor is due to insufficient intake of grains, fish and vegetables as well as too much fried food and beverages with added sugar and red meat. In finding the correlations between biological and sociodemographic variables and risk factors, we found some correlations. The results also show that unhealthy nutrition is more frequent among the population with below average material standards and lower educational levels, people living in smaller communities, the young, people with high BMI, those living in eastern regions of Slovenia and students.
\end{abstract}

Conclusion: The results indicate that more effort should be made to target activities towards those groups where several risk factors were found and develop a complex approach to developing healthy nutritional life styles.

Key words: nutrition, nutritional habits, risk factors, adults, Slovenia

Izvirni znanstveni članek UDK 613.2:614(497.4)

\section{Izvleček}

Uvod: Opravljena je bila analiza pojavljanja dejavnikov tveganja nezdravega načina prehranjevanja med odraslimi prebivalci Slovenije glede na biološke in sociodemografske spremenljivke.

Metode: Raziskovalna metoda je deskriptivna in kvantitativna. Podatki so bili zbrani strukturirano, z osebnim anketiranjem na terenu. Vzorec je zajemal 1.193 odraslih prebivalcev Slovenije. Spremljane biološke in sociodemografske spremenljivke smo povezovali z izbranimi dejavniki modela zdravega prehranjevanja. Izsledke smo ovrednotili s statistično analizo s pomočjo računalniškega programa SPSS.

Rezultati: Ugotovili smo, da ima le 4,7\% anketiranih zdrave prehranjevalne navade, še ustrezno prehranjevanje ima 22,5\% anketiranih, pri 62,8\% anketiranih pa prehranjevanje označujemo kot nezdravo. Najpogosteje anketirani uživajo premalo žit in žitnih izdelkov ter rib, premalo zelenjave, preveč ocvrte hrane, pijač z dodanim sladkorjem in rdečega mesa. Ugotovili smo povezanost bioloških in sociodemografskih spremenljivk z nekaterimi dejavniki tveganja. Izsledki raziskave tudi kažejo, da je nezdravo prehranjevanje pogosteje prisotno med prebivalci s podpovprečnim gmotnim standardom, z osnovnošolsko izobrazbo, pri prebivalcih manjših krajev, mladih, ljudeh z visokim ITM, v vzhodnoslovenski regiji in pri tistih, ki imajo status študenta. 


\begin{abstract}
Zaključek: Glede na izsledke ocenjujemo, da je treba več aktivnosti ciljno usmeriti v skupine, ki so bolj obremenjene $z$ dejavniki tveganja, oblikovati več ciljno usmerjenih implementacijskih aktivnosti in poudariti celosten pristop $k$ zagotavljanju zdravega življenjskega sloga, katerega pomemben del so prehranjevalne navade.
\end{abstract}

Ključne besede: prehrana, prehranske navade, dejavniki tveganja, odrasli, Slovenija

\section{INTRODUCTION}

Various unhealthy habits are linked to the risk of disease. Smoking, alcohol consumption, leading a physically inactive lifestyle and unhealthy eating habits as well as various combinations of these habits are linked to an increased risk of emergence of various diseases, particularly cardiovascular diseases and various types of cancer (1-3).

Healthy nutritional habits play an important role in maintaining people's health (4), while unhealthy eating habits greatly contribute to the development of chronic noncommunicable diseases, e.g. obesity, diabetes and heart and coronary diseases. Thus, healthy nutrition is regarded as a protective factor for maintaining health and quality of life $(5,6)$. In developed, as well as developing countries, the rates of chronic noncommunicable diseases are rapidly increasing and pose a serious problem to public health (7). Acquiring healthy habits greatly depends on the environment people live in and in particular on social determinants of health (8). Unhealthy nutrition includes several factors such as nutritional rhythm, nutritional and energy value of food, imbalanced meals and the way the food is prepared and consumed (9-13).

Among risk factors, the World Health Organisation (WHO) puts unhealthy nutrition in the forefront. This involves unsuitable consumption of fruits and vegetables, excessive use of salt and the content of saturated trans-fatty acids in food (14).

Another risk factor is precarious nutritional rhythm as opposed to correct nutrition rhythm. Precarious nutritional rhythm is characterised particularly by irregular meals and is connected with various external and internal factors. The results of research indicate that correct nutritional rhythm contributes to the improvement of lipid profile and reduction of total cholesterol levels and improvement of glucose tolerance $(15,16)$. Correct nutritional rhythm means having three to six meals a day: three main meals (breakfast, lunch, dinner) and one to three complementary meals, i.e. snacks. Irregular meals, skipping meals and improper nutritional rhythm are the main risk factors for the development of chronic noncommunicable diseases, malaise and work productivity (17).

Healthy nutrition means eating varied food and having nutritionally balanced menus composed of food of animal and vegetable origin (18). According to WHO recommendations, carbohydrates should cover 50 to $75 \%$ of daily energy needs, fats 15 to $30 \%$ and proteins from 10 to $15 \%$ (19). Healthy nutrition gives priority to foods that contain natural health protecting ingredients and contain small amounts of fats, particularly saturated and trans-fatty acids, simple sugars and lots of fibre and other various protective substances. According to $\mathrm{WHO}$, each daily meal should contain fruits and vegetables, whole-grain food and good quality fats, low-fat milk and dairy products and a reasonable amount of lean meat and fish. Only rarely should people consume food with high content of fats and sugars and beverages with added sugar (19).

The results of the study done on nutritional habits in Slovenia, carried out in 2001, 2004 and 2008, showed some dietary deficiencies among the adult population due to incorrect nutritional rhythm, excessive amounts of health hazardous fats and salt in food and insufficient quantities of fruits and vegetables in diets (20). Such nutritional habits present a serious risk as well as a general public health problem.

At the national level, the government adopted a resolution on nutrition policy for the years 2005-2010 that was basically aimed at setting up, maintaining and strengthening healthy nutritional habits of Slovenians. The mid-term goals included increasing the consumption of fruits and vegetables, reducing the intake of saturated fats and increasing the intake of food fibre, calcium and vitamin C (21).

Within the framework of the international CINDI program, some recommendations for healthy nutrition have been proposed. These include introducing more food stuffs of plant as well as animal origin, more whole grain food, having varied diets with locally produced fresh fruits and vegetables, monitoring the amounts of fat intake and replacing saturated fats with unsaturated ones, replacing greasy and meat products with legumes, fish, poultry or lean meat, consuming recommended amounts of low-fat milk and dairy products, eating less salty food and reducing the amounts of sugar and sweets (22).

Healthy nutrition is defined by the criteria cited above, aiming at promoting healthy nutritional styles for the Slovenian population (6). 
In our research, we focused on the general criteria of unhealthy nutrition and analysed the risk factors that contribute to the development of chronic noncommunicable diseases.

We studied the frequency of risk factors due to unhealthy nutrition among the adult population in Slovenia with regard to biological and sociodemographic variables.

\section{METHODOLOGY}

The presented research is a cross-sectional epidemiological study. The research was made using a structured interview with individuals. Structured personal interviews were carried out individually at the homes of the surveyed persons, taking 45 minutes on average. The interviewers carrying out the surveys received prior training at an educational seminar.

A special questionnaire that contained 108 groups of food was devised and adapted to the nutritional and cultural characteristics of the researched population. The interviewees estimated the frequency of their consuming a particular food or a group of foods.

A sample of respondents was obtained from the Central register of population of Slovenia. The sample included 2,381 randomly selected persons, and 1,193 of them completed the entire survey. On the basis of analysed causes for non-response in the research mentioned by the persons who refused to participate, we estimated that, regarding specific characteristics of the sample, they do not differ from the persons who agreed to participate in the research. The most frequent cause of nonresponse mentioned was being too busy $(36.9 \%$ of the sample) and a dislike of surveys in principle (28.7\% of the sample). The sample encompassed 1,193 randomly selected adult individuals from Slovenia from 18 to 65 years regardless of their health and nutritional condition as well as physical activity. To study biological and sociodemographic variables, the respondents were classified into various groups, presented in Table 1.

Table 1. Criteria for the formation of groups with regard to biological and sociodemographic characteristics. Tabela 1. Kriteriji za oblikovanje skupin glede na obravnavane biološke in sociodemografske značilnosti.

\begin{tabular}{|c|c|}
\hline $\begin{array}{l}\text { Biological and sociodemographic variables/ Biološke in } \\
\text { socio-demografska spremenljivka }\end{array}$ & $\begin{array}{l}\text { Value or group of the variable/ Vrednost oziroma razred } \\
\text { spremenljivke }\end{array}$ \\
\hline Sex/Spol & Male, female/ Moški, ženski \\
\hline Age (years)/ Starost (leta) & 18 to 25,26 to 45,46 to $65 / 18$ do 25,26 do 45,46 do 65 \\
\hline Body mass index (BMI)/ Indeks telesne mase (ITM) & $\begin{array}{l}\text { Up to } 19.99 \text {, from } 20.00 \text { to } 24.99 \text {, from } 25.00 \text { to } 26.99 \text {, } \\
27.00 \text { or above/ Do } 19.99 \text {, od } 20 \text { do } 24.99 \text {, od } 25.00 \text { do } \\
26.99,27.00 \text { ali več }\end{array}$ \\
\hline Education/ Izobrazba & $\begin{array}{l}\text { Elementary, secondary, higher and above/ } \\
\text { Osnovnošolska, srednješolska, višja ali več }\end{array}$ \\
\hline $\begin{array}{l}\text { Material status according to the respondent/ Materialni } \\
\text { standard na osnovi opredelitve anketiranca }\end{array}$ & $\begin{array}{l}\text { Under average, average, above average/ Podpovprečen, } \\
\text { povprečen, nadpovprečen }\end{array}$ \\
\hline Type of employment/ Zaposlitveni status & $\begin{array}{l}\text { Self employed (full time), Self employed (part time), } \\
\text { student, retired, housewife, farmer and farmer housewife, } \\
\text { unemployed, other/ Samozaposlen za polni delovni čas, } \\
\text { samozaposlen za določen delovni čas, } \\
\text { študent, upokojenec, gospodinja, kmetovalec in kmečka } \\
\text { gospodinja, brezposeln, drugo }\end{array}$ \\
\hline $\begin{array}{l}\text { Type of community according to the number of } \\
\text { inhabitants/ Tip naselja glede na število prebivalcev }\end{array}$ & $\begin{array}{l}\text { Up to } 2000 \text { inhabitants, } \\
2,000 \text { to } 50,000 \text { inhabitants, } \\
\text { above } 50,000 \text { inhabitants/ Do } 2000 \text { prebivalcev, } 2000 \\
\text { do } 50000 \text { prebivalcev, } \\
\text { nad } 50000 \text { prebivalcev }\end{array}$ \\
\hline Region/ Regija & $\begin{array}{l}\text { Western, central, eastern region/ Zahodna, osrednja, } \\
\text { vzhodna }\end{array}$ \\
\hline
\end{tabular}


Slovenia has not yet formed official criteria of the Healthy Eating Index to be used to establish the quality of nourishment of the population. Following the WHO recommendations (19) and the data obtained from other research (23-27), we selected and defined ten risk factors of unhealthy eating habits, which are presented in Table 2.

Table 2. Risk factors for the assessment of unhealthy nutrition and criteria for the assessment of unhealthy nutritional behaviour.

Tabela 2. Dejavniki tveganja za oceno nezdravega prehranjevanja in kriteriji nezdravega vedenja.

\begin{tabular}{|c|c|c|}
\hline $\begin{array}{l}\text { Risk factors/ } \\
\text { Dejavniki tveganja }\end{array}$ & Description of risk/ Opis dejavnika & $\begin{array}{l}\text { Criteria for unhealthy behaviour/ Kriterij za nezdravo } \\
\text { vedenje }\end{array}$ \\
\hline 1 & $\begin{array}{l}\text { Number of daily meals/ Število } \\
\text { dnevnih obrokov }\end{array}$ & 2 or less/ 2 ali manj \\
\hline 2 & $\begin{array}{l}\text { Milk and dairy products } \\
\text { consumption frequency/ } \\
\text { Pogostost uživanja mleka in } \\
\text { mlečni izdelki }\end{array}$ & $\begin{array}{l}\text { Less than once a day/ } \\
\text { Manj kot enkrat na dan }\end{array}$ \\
\hline 3 & $\begin{array}{l}\text { Frequency of vegetable } \\
\text { consumption/ Pogostost uživanja } \\
\text { zelenjave }\end{array}$ & Less than once a day/ Manj kot enkrat na dan \\
\hline 4 & $\begin{array}{l}\text { Frequency of fruit consumption/ } \\
\text { Pogostost uživanja sadja }\end{array}$ & Less than once a day/ Manj kot enkrat na dan \\
\hline 5 & $\begin{array}{l}\text { Frequency of red meat } \\
\text { consumption/ Pogostost uživanja } \\
\text { rdečega mesa }\end{array}$ & Three times a week or more/ Trikrat na teden ali več \\
\hline 6 & $\begin{array}{l}\text { Frequency of fish and sea food } \\
\text { consumption/ Pogostost uživanja } \\
\text { rib in morskih sadežev }\end{array}$ & Three times a month or less/ Trikrat na mesec ali redkeje \\
\hline 7 & $\begin{array}{l}\text { Frequency of whole-grain cereals } \\
\text { consumption (groups of porridge, } \\
\text { groats...)/ Pogostost uživanja } \\
\text { polnozrnatih žit (kosmiči ali kaše) }\end{array}$ & Three times a month or less/ Trikrat na mesec ali redkeje \\
\hline 8 & $\begin{array}{l}\text { Frequency of fried food } \\
\text { consumption/ Pogostost uživanja } \\
\text { ocvrte hrane }\end{array}$ & Once a week or more/ Enkrat na teden ali pogosteje \\
\hline 9 & $\begin{array}{l}\text { Additional use of salt/ Dosoljevanje } \\
\text { hrane }\end{array}$ & $\begin{array}{l}\text { Adding salt without tasting food first/ Dosoljevanje brez } \\
\text { predhodnega pokušanja }\end{array}$ \\
\hline 10 & $\begin{array}{l}\text { Drinks with added sugar (fizzy } \\
\text { drinks, still drinks, water with } \\
\text { added flavour, fruit syrup)/ } \\
\text { Pogostost uživanja pijač z } \\
\text { dodanim sladkorjem (gazirane, } \\
\text { negazirane, voda z okusom, } \\
\text { sadni sirupi) }\end{array}$ & $\begin{array}{l}\text { Four to six times a week of more/ Štirikrat do šestkrat } \\
\text { na teden ali pogosteje }\end{array}$ \\
\hline
\end{tabular}

The criteria are based on the frequency of consuming foods from particular food groups and were formed on the basis of available data obtained from results of the research, and, to allow comparison of data, they were at the same time adapted to the criteria used in the 2004 research (28). For most of the selected criteria (risk factors 1-4, 6 and 7 in Table 2), unhealthy eating habits are defined as the frequency value of consuming regular meals and particular foods that is considered as insufficient frequency in literature (23-26). In criteria 3 and 4 that deal with consumption of fruits and vegetables, a valid measure of diet quality used 
to define the "minimum score criteria" in the article by McNaughton at al. (24) was taken as the criterion of unhealthy eating habits. In the seventh criterion that deals with consumption of whole-grain cereals, the frequency of consuming whole-grain porridges and groats was taken into account, since data for other whole-grain products was unavailable.

The data were processed by statistical analysis, using the SPSS program. First, the differences between average values of the frequency of risk factors in correlation to biological and sociodemographic variables were verified by using T-test for independent samples and variance analysis ANOVA. To determine the differences between individual groups within variables, we carried out unplanned (a posteriori) multiple comparisons (post hoc test). The Pearson's chi-squared test was applied to infer the differences between attributive variables. For statistical inference, we considered 0.05 the degree of risk.

\section{RESULTS}

The frequency analysis of risk factors showed that in more than fifty percent of the population in Slovenia, the risk factors appear in the category of fruits and vegetables, fish and sea food and cereals (Table 3 ).

Table 3. Number and percentage of the respondents in correlation with risk factors.

Tabela 3. Število in delež anketirancev glede na posamezni dejavnik tveganja.

\begin{tabular}{|l|l|l|l|}
\hline \multicolumn{2}{|l|}{ Risk factors/ Dejavniki tveganja } & $\mathrm{f}$ & $\mathrm{f}(\%)$ \\
\hline 1 & $\begin{array}{l}\text { Number of meals/ } \\
\text { Dnevno število obrokov }\end{array}$ & 437 & 36.7 \\
\hline 2 & $\begin{array}{l}\text { Milk and dairy products/ } \\
\text { Mleko in mlečni izdelki }\end{array}$ & 425 & 35.7 \\
\hline 3 & Vegetables/ Zelenjava & 667 & 56.4 \\
\hline 4 & Fruit/ Sadje & 376 & 31.8 \\
\hline 5 & Red meat/ Rdeče meso & 506 & 42.5 \\
\hline 6 & $\begin{array}{l}\text { Fish and sea food/ } \\
\text { Ribe in morski sadeži }\end{array}$ & 688 & 57.9 \\
\hline 7 & $\begin{array}{l}\text { Whole-grain cereals/Polnozrnati } \\
\text { žitni kosmiči in kaše }\end{array}$ & 806 & 67.7 \\
\hline 8 & Fried food/ Ocvrta hrana & 570 & 47.9 \\
\hline 9 & $\begin{array}{l}\text { Adding salt without tasting food } \\
\text { first/ Dosoljevanje hrane }\end{array}$ & 36 & 3.0 \\
\hline 10 & $\begin{array}{l}\text { Drinks with added sugar/ Pijače } \\
\text { z dodanim sladkorjem }\end{array}$ & 524 & 44.1 \\
\hline
\end{tabular}

Adding salt without tasting food first is a less frequent factor and occurs in only $3.0 \%$ of the population. The factor that accounts for $36.7 \%$ of the population is due to improper number of meals per day, while $35.7 \%$ of the population consume milk and dairy products less than once a day (Table 3).

We wanted to determine statistical significance of individual risk factors correlated with biological and sociodemographic variables (Table 4). We found that there is a statistical correlation between nine risk factors and gender. In all risk factors where we found statistical significant correlation, the percentage of males is higher than in females. Education is the second most important factor: in six risk factors (numbers 4, 5, 6, 7,8 and 10), it was found that the smallest share per particular risk factor is accounted for by persons with higher education, while the risk factor related to irregular intake of meals (number 1) and vegetables (number 3 ) is least frequent with persons with elementary education. Education status correlates with eight risk factors, however it is not proven that a particular status is markedly correlated with several risk factors. The analysis showed that the percentage of those who regularly have at least three meals a day is highest among farmers and farmer housewives. The latter most frequently consume fruits and vegetables and least frequently meat. As for employment status, the smallest risk due to the consumption of cereals and red meat was found among students. As for the age factor, the percentages of risk factors $1,3,4,8$ and 10 are highest among persons within the age group from 46 to 65 years, with the exception of risk factor 7 where the percentage is lowest among persons between 18 to 25 years. Statistical correlation between regions and risk factors was found with factors 2, 3, 5, 6, 8 and 10. Most persons with five risk factors $(2,3,5,8$ and 10) come from eastern regions of Slovenia. Our research also showed a correlation between the size of the community the respondents live in and risk factors. People coming from communities with more than 50,000 inhabitants consume less red meat, beverages with added sugar, fried food and cereals, while this is most frequent in communities with 2,000 inhabitants. A correlation between risk factors and BMI was found in factors 1,5 , 7 and 10: the lowest percentage of risk factors 1,5 and 7 was found in the group of respondents with BMI below 20.00 , while the highest percentage with persons with BMI 27.00 or above correlate with risk factors 1 and 7 . Material status correlates only with risk factors 5 and 7. The highest percentage of persons with these two risk factors was found among those with below average 
material status and the lowest among those with above average material status.

If we take a look at the horisontal lines in Table 4, we can see that the lowest correlation is between the risk of adding salt to food and biological and sociodemographic factors. A low correlation is also observed in the consumption of milk and dairy products, fish and sea food. On the other hand, higher correlation was found between the risk factors related to the consumption of red meat, cereals and beverages with added sugar.

Table 4. Correlation between risk factors and biological and sociodemographic characteristics.

Tabela 4. Pregledna tabela povezanosti dejavnikov tveganja z biološkimi ter sociodemografskimi značilnostmi.

\begin{tabular}{|c|c|c|c|c|c|c|c|c|c|}
\hline \multicolumn{2}{|c|}{$\begin{array}{l}\text { Risk factors/ } \\
\text { Dejavniki tveganja }\end{array}$} & \multirow{2}{*}{$\begin{array}{c}\text { Sex/ } \\
\text { Spol } \\
\\
*\end{array}$} & \multirow{2}{*}{\begin{tabular}{|l|} 
Standard/ \\
Standard
\end{tabular}} & \multirow{2}{*}{$\begin{array}{c}\text { Education/ } \\
\text { Izobrazba } \\
*\end{array}$} & \multirow{2}{*}{$\begin{array}{l}\text { Type of } \\
\text { community/ } \\
\text { Tip naselja }\end{array}$} & \multirow{2}{*}{$\begin{array}{c}\text { Age/ } \\
\text { Starost } \\
\\
\text { * }\end{array}$} & \multirow{2}{*}{$\begin{array}{l}\text { BMI/ } \\
\text { ITM } \\
\text { * }\end{array}$} & \multirow{2}{*}{$\begin{array}{l}\text { Region/ } \\
\text { Regija }\end{array}$} & \multirow{2}{*}{\begin{tabular}{l} 
Employment \\
status/ \\
Zaposlitveni \\
status \\
\multicolumn{1}{c}{$*$}
\end{tabular}} \\
\hline 1 & $\begin{array}{l}\text { Number of daily } \\
\text { meals/ Dnevno } \\
\text { število obrokov }\end{array}$ & & & & & & & & \\
\hline 2 & $\begin{array}{l}\text { Milk and dairy } \\
\text { products/ } \\
\text { Mleko in mlečni } \\
\text { izdelki }\end{array}$ & * & & & & & & * & \\
\hline 3 & $\begin{array}{l}\text { Vegetables/ } \\
\text { Zelenjava }\end{array}$ & * & & * & & * & & * & * \\
\hline 4 & Fruit/ Sadje & * & & * & & * & & & * \\
\hline 5 & \begin{tabular}{|l|} 
Red meat// \\
Rdeče meso
\end{tabular} & * & * & * & * & & * & * & * \\
\hline 6 & $\begin{array}{l}\text { Fish and sea } \\
\text { food/ Ribe in } \\
\text { morski sadeži }\end{array}$ & & & * & & & & * & * \\
\hline 7 & $\begin{array}{l}\text { Whole-grain } \\
\text { cereals/ } \\
\text { Polnozrnati } \\
\text { žitni kosmiči in } \\
\text { kaše }\end{array}$ & * & * & * & * & * & * & & * \\
\hline 8 & $\begin{array}{l}\text { Fried food / } \\
\text { Ocvrta hrana }\end{array}$ & * & & * & * & * & & * & \\
\hline 9 & $\begin{array}{l}\text { Adding salt/ } \\
\text { Dosoljevanje } \\
\text { hrane }\end{array}$ & * & & & & & & & \\
\hline 10 & $\begin{array}{l}\text { Drinks with } \\
\text { added sugar/ } \\
\text { Pijače z } \\
\text { dodanim } \\
\text { sladkorjem }\end{array}$ & * & & * & * & * & * & * & * \\
\hline
\end{tabular}

Legend/ Legenda: * $p<0.05$

In our study, we correlated the frequency of individual risk factors with different variables to find that on average there are 4.2 risk factors that endanger the health of Slovenians. The percentage of those who have developed nutritional habits with five or more risk factors is $43.9 \%$, and only $1.8 \%$ have no risk factor. The largest share $(21.4 \%)$ is accounted for by those with four risk factors (Table 5). 
Table 5. Percentage of persons and the number of risk factors.

Tabela 5. Delež oseb s posameznim številom dejavnikov tveganja.

\begin{tabular}{|c|c|c|}
\hline $\begin{array}{l}\text { Number of risk factors/ } \\
\text { Število dejavnikov tveganja }\end{array}$ & $\mathrm{f}$ & $\mathrm{f}(\%)$ \\
\hline 0 & 21 & 1.8 \\
\hline 1 & 64 & 5.5 \\
\hline 2 & 136 & 11.6 \\
\hline 3 & 184 & 15.7 \\
\hline 4 & 250 & 21.4 \\
\hline 5 & 217 & 18.6 \\
\hline 6 & 178 & 15.2 \\
\hline 7 & 73 & 6.2 \\
\hline 8 & 34 & 2.9 \\
\hline 9 & 12 & 1.0 \\
\hline Total/ Skupaj & 1,169 & 100.0 \\
\hline
\end{tabular}

The correlation between risk factors and biological variables, where we considered the gender and body mass index of the respondents, indicates that the average number of risk factors among the male population is ( $M=4.85)$, which is statistically more significant $(p<0.05)$, and the average number of risk factors among females is $(M=3.72$ ) (Table 6).

We also found that the number of risk factors decreases by age (Table 7). The smallest percentage of risk factors was found among adults between 46 and 65 years of age $(M=4.96)$, and the highest among persons between 18 and 25 years $(M=4.82)$. A multiple comparison test on the average number of risk factors showed that the difference between age groups is statistically significant $(p<0.05)$.

The analysis of risk factors by different groups of respondents according to their BMI showed no statistically significant differences $(p>0.05)$ - Table 7 .

Table 6. Number of risk factors and gender.

Tabela 6. Število dejavnikov tveganja glede na spol.

\begin{tabular}{|l|l|c|c|c|}
\hline Gender/ Spol & $\begin{array}{l}\text { Risk } \\
\text { factors (M)/ } \\
\text { Dejavniki } \\
\text { tveganja (M) }\end{array}$ & SD & $\mathrm{t}$ & $\mathrm{p}$ \\
\cline { 1 - 3 } Male/ Moški & 4.85 & 1.72 & 10.829 & 0.000 \\
\hline Female/ Ženske & 3.72 & 1.81 & & \\
\hline
\end{tabular}

Among demographic variables, we considered the material standard of the respondents, level of education, size of the community they live in, region and employment status. As far as the material standard is concerned, the highest number of risk factors was found among persons with below average standard ( $M$ $=4.61)$, and the lowest $(M=3.91)$ among persons with above average material standard. Multiple comparison test between the groups showed that there is a statistically significant difference between a person with below average standard and those with average or above average standard, while no such statistical difference was found in persons between average and above average standard ( $p>0.05)$.

Correlation with level of education shows that persons with higher education have the fewest health risk factors $(M=3.59)$, while the differences between the respondents with elementary and secondary education show no statistical significance. Persons living in towns with more than 50,000 inhabitants have fewer risk factors $(M=3.96)$ compared to those who live in smaller communities $(p<0.05)$. The average number of risk factors in persons living in smaller $(M=4.34)$ and medium sized communities ( $M=4.10)$ is statistically insignificant (Table 7).

A correlation between risk factors and geographical region indicates that the lowest rate of risk factors is found in western regions of Slovenia $(M=3.94)$. With multiple comparison test between regions, we found that the eastern region stands out $(M=4.48)$ and differs both from the western and central region ( $M=$ 4.07). There are no statistically significant differences between the western and central regions in Slovenia $(p=0.387)$ - Table 7.

As for employment status, the highest rate of risk factors was found among the student population $(M=4.55)$ and among retired persons $(M=3.69)$. By multiple comparison calculations between the retired population and other groups, we noticed some statistically significant differences within the group of self-employed people with part time employment $(p=0.00)$, students $(p=0.00)$, farmers and farmer housewives $(p=0.05)$ and unemployed people $(p=0.04)$ - Table 7 . 
Table 7. Average number of risk factors in correlation with demographic variables.

Tabela 7. Povprečna vrednost števila dejavnikov tveganja glede na demografske spremenljivke.

\begin{tabular}{|c|c|c|c|c|c|}
\hline $\begin{array}{l}\text { Biological and sociodemographic } \\
\text { variables/ Biološe in socio- } \\
\text { demografska spremenljivka }\end{array}$ & $\begin{array}{l}\text { Value or group of the variable/ } \\
\text { Vrednost oziroma razred } \\
\text { spremenljivke }\end{array}$ & $\begin{array}{c}\text { Risk } \\
\text { factors }(\mathrm{M}) / \\
\text { Dejavniki } \\
\text { tveganja }(\mathrm{M}) \\
\end{array}$ & SD & $\mathrm{F}$ & $\mathrm{p}$ \\
\hline \multirow{3}{*}{$\begin{array}{l}\text { Material standard/ Materialni } \\
\text { standard }\end{array}$} & Low/ Podpovprečen & 4.61 & 1.91 & \multirow[t]{3}{*}{5.693} & \multirow[t]{3}{*}{0.003} \\
\hline & Average/ Povprečen & 4.18 & 1.85 & & \\
\hline & Above average/ Nadpovprečen & 3.91 & 1.78 & & \\
\hline \multirow[t]{3}{*}{ Education/ Izobrazba } & $\begin{array}{l}\text { Elementary or less/ Osnovna } \\
\text { šola ali manj }\end{array}$ & 4.38 & 1.88 & \multirow[t]{3}{*}{18.504} & \multirow[t]{3}{*}{0.000} \\
\hline & $\begin{array}{l}\text { Vocational or secondary/ } \\
\text { Poklicna ali srednja šola }\end{array}$ & 4.38 & 1.86 & & \\
\hline & Higher or above/ Višja ali več & 3.59 & 1.69 & & \\
\hline \multirow{3}{*}{$\begin{array}{l}\text { Place of living (number of } \\
\text { inhabitants)/ Kraj bivanja glede na } \\
\text { število prebivalcev }\end{array}$} & Up to $2,000 /$ Do 2,000 & 4.34 & 1.78 & \multirow[t]{3}{*}{3.950} & \multirow[t]{3}{*}{0.020} \\
\hline & $\begin{array}{l}\text { from } 2,000 \text { to } 50,000 / \text { Od } 2,000 \\
\text { do } 50,000\end{array}$ & 4.10 & 1.92 & & \\
\hline & $\begin{array}{l}\text { More than 50,000/ Več kot } \\
50,000\end{array}$ & 3.96 & 2.00 & & \\
\hline \multirow[t]{3}{*}{ Age (years)/ Starost (leta) } & Up to $26 /$ Do 26 & 4.82 & 1.78 & \multirow[t]{3}{*}{15.594} & \multirow[t]{3}{*}{0.000} \\
\hline & From 26 to 45 / Od 26 do 45 & 4.24 & 1.89 & & \\
\hline & 46 or above/ Več kot 46 & 3.95 & 1.81 & & \\
\hline \multirow[t]{4}{*}{$\mathrm{BMI} / \mathrm{ITM}$} & Up to 19.99/ Do 19.99 & 4.01 & 1.79 & \multirow[t]{4}{*}{1.759} & \multirow[t]{4}{*}{0.153} \\
\hline & $\begin{array}{l}\text { From } 20 \text { to } 24.99 / \text { Od } 20 \text { do } \\
24,99\end{array}$ & 4.16 & 1.87 & & \\
\hline & $\begin{array}{l}\text { From } 25.00 \text { to } 26.99 \text { / Od } 25.00 \\
\text { do } 26.99\end{array}$ & 4.07 & 1.87 & & \\
\hline & 27.00 or above/ 27.00 ali več & 4.37 & 1.81 & & \\
\hline \multirow[t]{3}{*}{ Region/ Regija } & Western/ Zahodna & 3.94 & 1.82 & \multirow[t]{3}{*}{9.645} & \multirow[t]{3}{*}{0.000} \\
\hline & Central/ Osrednja & 4.07 & 1.88 & & \\
\hline & Eastern/ Vzhodna & 4.48 & 1.82 & & \\
\hline \multirow[t]{8}{*}{$\begin{array}{l}\text { Employment status/ Zaposlitveni } \\
\text { status }\end{array}$} & $\begin{array}{l}\text { Full time employees/ Polni } \\
\text { delovni čas }\end{array}$ & 4.32 & 1.82 & \multirow[t]{8}{*}{3.341} & \multirow[t]{8}{*}{0.002} \\
\hline & $\begin{array}{l}\text { Part-time employees/ Skrajšani } \\
\text { delovni čas }\end{array}$ & 3.83 & 2.40 & & \\
\hline & Student/ Študent & 4.55 & 1.89 & & \\
\hline & Retired persons/ Upokojen & 3.69 & 1.74 & & \\
\hline & Housewife/ Gospodinja & 4.28 & 1.87 & & \\
\hline & $\begin{array}{l}\text { Farmer and farmer housewife/ } \\
\text { Kmetovalec ali kmečka } \\
\text { gospodinja }\end{array}$ & 4.35 & 1.57 & & \\
\hline & Unemployed/ Brezposeln & 4.22 & 1.89 & & \\
\hline & Other/ Drugo & 4.28 & 1.92 & & \\
\hline
\end{tabular}




\section{DISCUSSION}

The study, which was carried out in Slovenia in 2004, showed that as much as $46.6 \%$ of the Slovenian population have developed unhealthy nutrition habits. The percentages with above average numbers of health risk factors were found among men between ages 30 to 39 and 40 to 49 years, those with completed vocational education, middle class employed persons and those coming from eastern Slovenian rural areas $(28,29)$. With these findings in mind, we wanted to compare whether the situation has changed after the implementation of the National Nutrition Policy Programme in $2005-2010$.

\section{Number of daily meals}

Since Fabry's thesis (30) was published, namely that the number of daily meals could potentially have impact on the development of pathological conditions, various authors have studied the impacts of the frequency of meals in correlation with different parameters (31).

The results from our study show that less than a third of respondents have two meals (or less) a day, and the percentage is even higher among the youngest population (50\%). Two meals a day is most frequent among fully employed people and students.

\section{Milk and dairy products}

Milk and dairy products are important sources of proteins and calcium and should be consumed on a daily basis, particularly low fat products.

Table 3 shows that insufficient consumption of milk and dairy products occurs in $35.7 \%$ of the population and is more expressed among men coming from the eastern Slovenian region.

\section{Vegetables and fruit}

Vegetables and fruits are the sources of vitamins and minerals and the sources of antioxidants that counteract oxidative stress $(32,33)$. For this reason, raw and cooked vegetables and fruit should be regularly incorporated into diets.

From the results of our research, we can infer that vegetables and fruits are frequently on the menus since there were no respondents who consume this food less than once a day. If we compare this with the results of the research from 1997, we can observe a positive trend - the percentage is now higher (34).

Regular consumption of vegetables and fruit decreases the risks of heart and coronary diseases (35), and for this reason and following the National nutrition policy (19) and WHO recommendations (36), this aspect of nutrition has been recently highly promoted and positive effects are already reflected in our study; we found that only $5.7 \%$ of the population consume fruit less than once a day.

\section{Red meat}

Some epidemiological studies have pointed out that there is a correlation between the consumption of red meat and meat products and cardiovascular diseases and colon cancer, while they also emphasise positive effects of n-3 polyunsaturated fatty acids and conjugated linoleic acid found in red meat (37). Some authors also emphasise the risks of red meat consumption for the development of cancer that is due to carcinogenic polycyclic amines formed during thermal processing of meat (38). Others point out synergistic effects between heterocyclic amines and fats in meat (3). A recommended amount of red meat is $300 \mathrm{~g}$ per week, which means a portion of meat less than three times a week (39).

As for red meat consumption, the results of our study indicate unhealthy behaviour among men with elementary education, those living in small communities and adults in the age group from 46 to 65 years.

\section{Fish}

It is generally known that fish contain omega-3 fatty acids, particularly docosahexanoic acid, and prevent coronary heart diseases and hypertension (40). It has been found that regular consumption of fish on a weekly basis has positive effects on the vitality of the brain and prevents Alzheimer disease (41). It has also been reported that the consumption of fish reduces the risks of sudden heart failure and myocardial infarction $(42,43)$. Nutrition experts recommend two meals of fish per week (44).

The data we have obtained show that fish is not frequently on menus, since $60 \%$ of the respondents consume fish and sea food less than three times per month (57.9\% - Table 3). Statistically significant differences have been found in groups with different education level, geographical region and employment standard.

\section{Whole-grain cereals}

Whole-grain cereals are a good source of dietary fibre. The results of our study show that $65 \%$ of the respondents consume whole-grain cereals maximum three times a month, and by this criterion we can consider this as unhealthy nutrition. Within different groups and correlations with variables, it seems that higher risks occur among men, persons with $\mathrm{BMI}$ above 27 , those with vocational education and persons living in smaller communities coming from western regions of Slovenia.

\section{Fried food}

Fried food elevates the content of fat in the blood and for this reason it should be scarcely used and reduced in diets (45). 
Our criterion was that fried food consumed once a week is unhealthy, and according to our study almost half of the respondents $(47.9 \%)$ consume fried food once a week. With regard to sociodemographic variables, fried food is more popular among men, the younger population and those with lower education from western regions of Slovenia.

\section{Adding salt}

Adding salt to food without previously tasting it is an acquired habit. Approximately $15 \%$ of the daily amount of salt is added during food preparation and cooking and during eating food at a table (46).

We found that $3 \%$ of the respondents add salt to food without previously tasting it. This is more frequent among men from the age group of 26 to 45 years and those with vocational education and lower material standard.

\section{Sweet non-alcoholic beverages}

Consumption of sweet non alcoholic beverages is another criterion of unhealthy nutrition and contributes to the development of obesity and leads to chronic noncommunicable diseases $(12,46)$. Such beverages include fizzy and still non alcoholic drinks, waters with added flavour and fruit syrups. In our study, we found that as much as $44 \%$ of the respondents consume sweet drinks four to six times a week, which is considered as a bad nutritional habit. This is most frequent among men with lower education, persons with BMl above 27 and those living in smaller communities.

Percentage of the respondents in correlation with risk factors

According to our results (Table 3), we can conclude that the percentages we have obtained by analysing different risk factors vary. The majority of the respondents $(36.1 \%)$ have two or even less meals. Since this risk factor has already been identified in our previous research $(14,47)$, we can conclude that since 2010, during the implementation of the nutrition policy programme, no improvement has been made (21). Correlation between risk factors and biological and sociodemographic characteristics showed statistically significant differences between males and females, different education, geographical region, age and employment status (Table 4).

\section{CONCLUSION}

The results of our study show that a significant percentage of the population in Slovenia still has unhealthy nutritional habits that are not along the lines of the recommendations for healthy nutrition $(10,20$, $28,48)$.
It was found that only $4.7 \%$ of the people practice healthy nutritional habits without any risk factors, $22.5 \%$ of the respondents have one or two risk factors that can be considered as still acceptable and as much as $62.8 \%$ of the respondents had several risk factors, which is considered as unhealthy nutrition. In the study that was carried out in 2004, the share of those with unhealthy nutrition was $46.6 \%$ (28), however the methodologies applied in the two studies are not comparable.

The results of the research are a significant indicator of the general state of occurrence of nutritional risk factors among the Slovenian population. They represent a starting point for designing studies through which particular nutritional risk factors can be studied in detail and to form national criteria (diet quality indices) of unhealthy eating habits. These criteria could be employed to monitor, on a larger scale, the eating habits of the Slovenian population and to compare them in longitudinal epidemiological studies as well as to find correlations with other health risk factors.

The most frequent risk factors are the lack of wholegrain cereals and fish and vegetables consumption, followed by too much fried food, beverages with added sugar and red meat as well as improper number of daily meals and milk and dairy consumption, followed by insufficient quantities of fruits and risks due to adding salt to food.

Correlating the biological and sociodemographic factors with risk factors, we found that most risk factors correlate with gender, education, employment status, age, region, size of the community, nutritional status and material standard.

The results show that unhealthy nutrition is more frequent among people with below average material standard, elementary education, those living in smaller communities, the young, those with high BMl, those living in eastern regions of Slovenia and among students. We can infer that nutritional habits of the male population are poorer, which means that men have a greater chance for the development of diseases.

For all these reasons together with the fact that people are not responding to recommendations for healthy nutrition, future actions should be targeted at the groups where we found several risk factors.

We believe that our results can contribute to the preparation and implementation of a new national nutrition policy, since the results indicate those sociodemographic population groups that show a higher incidence of the analysed nutritional health risks and the population groups that require priority treatment. A solution to reduce sociodemographic differences among the population is to continue the measures 
for reducing the sociodemographic differences and to develop programs for the promotion of healthy lifestyle, which means that a complex approach should be taken in which nutrition is an important factor.

Besides appropriate nutrition, physical activity of the population and their giving up unhealthy habits such as smoking and alcohol consumption should be promoted in order to maintain and improve the health of the population (49).

\section{References}

1. World Health Organization. Global status report on noncommunicable diseases 2010. Geneva: World Health Organization, 2011. Available Jun 15, 2013 at: http://whqlibdoc. who.int/publications/2011/9789240686458_eng.pdf.

2. Lim SS, Vos T, Flaxman AD, Danaei G, Shibuya K, Adair Rohani $\mathrm{H}$ et al. A comparative risk assessment of burden of disease and injury attributable to 67 risk factors and risk factor clusters in 21 regions, 1990-2010: a systematic analysis for the Global Burden of Disease Study 2010. Lancet 2012; 380: 2224-60.

3. Jantine Schuit A, Van Loon JM, Tijhuis M, Ocke MC. Clustering of lifestyle risk factors in a general adult population. Prev Med 2002; 35: 219-24.

4. World Health Organization. Diet, nutrition and the prevention of chronic diseases: report of a joint WHO/FAO Expert Consultation. Geneva: World Health Organization, 2003.

5. Hlastan Ribič C. Zdrava prehrana kot temelj zdravja. In: Hlastan-Ribič C, editor. Cvahtetovi dnevi javnega zdravja 2010, Zdrava prehrana in javno zdravje: zbornik prispevkov. Ljubljana: Univerza v Ljubljani, Medicinska fakulteta, 2010: 5-26.

6. Gabrijelčič Blenkuš M, Kuhar D. Prehranjevalne navade in prehranski status - pregled stanja v Sloveniji in svetu. In: Gabrijelčič Blenkuš $M$, editor. Prehrambene navade odraslih prebivalcev Slovenije z vidika varovanja zdravja II. Ljubljana: Univerza v Ljubljani, Pedagoška fakulteta, 2009: 9-21.

7. European Health for All Database (HFA-DB). World Health Organization,. 2012. Available Dec 15, 2012 at: http://www.euro. who.int/hfadb.

8. World Health Organization. Closing the gap in a generation: commision on social determinants of health report. Geneva: World Health Organization, 2008.

9. Pokorn D. Zdrava prehrana in dietni jedilniki: priročnik za praktično predpisovanje diet. Zdrav Var 1997; 36 (Suppl 8): 22-33.

10. Koch V. Prehrambene navade odraslih Slovencev z vidika varovanja zdravja: doktorska disertacija. Ljubljana: Biotehnična fakulteta, 1997.

11. Whitney EN, Cataldo C B, Rolfes S R. Understanding normal and clinical nutrition. 6th ed. Belmont: Wadsworth Thomson Learning, 2002.

12. Insel PM, Turner RE, Ross D. Nutrition. 2nd ed. London: Jones and Bartlett, 2004.

13. Brown JE. Nutrition through the life cycle. 3th ed. Belmont: Wadsworth, Thomson Learning, 2008.

14. World Health Organization. Obesity and overweight. Available Dec 10, 2012 at: http://www.who.int/mediacentre/factsheets/ fs311/en/.

15. Louis Sylvestre J, Llunch A, Neant F, Blundell JE. Highlighting the positive impact of increasing feeding frequency on metabolism and weight management. Forum Nutr 2003; 56: 126-8.

16. Gatenby SJ. Eating frequency: metodological and dietary aspects. Br J Nutr 1997; 77(Suppl 1): 7-20.
17. Pokorn D, Maučec Zakotnik J, Močnik Bončina U, Koroušić Seljak B. Smernice zdravega prehranjevanja delavcev v delovnih organizacijah. Ljubljana: Ministrstvo za zdravje Republike Slovenije, 2008.

18. National Research Council. Diet and health: implication for reducing chronic disease risk: report of the Committee on Diet and Health, Food and Nutrition Board, Commission on Life Sciences. Washington: Academy Press, 1989.

19. World Health Organization. Diet, nutrition and the prevention of chronic diseases. Geneve: World Health Organization, 2003.

20. Inštitut za varovanje zdravja Republike Slovenije. Z zdravjem povezan vedenjski slog. Available Nov 26, 2012 at: http://www. ivz.si/Mp.aspx?ni=78\&pi=6\&_6_id=2196\&_6_Pagelndex=1\&_6_ groupld=-2\&_6_newsCategory=IVZ+kategorija\&_6_ action=ShowNewsFull\&pl=78-6.0.g 2012.

21. Ministrstvo za zdravje Republike Slovenije. Resolucija o nacionalnem programu prehranske politike 2005-2010. 2005. Ur List RS (39): 3681-719.

22. CINDI. 12 korakov do zdravega prehranjevanja. Available Oct 2, 2012 at: http://www.cindi-slovenija.net/index.php?option=com content\&id=128\&ltemid $=128$.

23. Status report on the European Commision's work in the field on nutrition in Europe. Bruxelles: European Comission, 2002.

24. McNaughton SA, Ball K, Crawford D, Mishra GD. An index of diet and eating patterns is a valid measure of diet quality in an Australian population. J Nutrition 2007; 138: 86-93.

25. Dubois L, Girard M, Bergeron N. The choice of a diet quality indicator to evaluate the nutritional health of populations. Public Health Nutr 2000; 3: 357-65.

26. Kant AK. Indexes of overall diet quality: a review. J Am Diet Assoc 1996; 96: 785-91.

27. Koch V, Pokorn D. Comparison of nutritional habits among various adult age groups in Slovenia. Nutr Res 1999; 19: 1153-64.

28. Zaletel Kragelj L, Pavčič M, Koch V, Maučec Zakotnik J. Nezdravo prehranjevanje. In: Zaletel Kragelj L, Fras Z, MaučecZakotnik J. editors. Tvegana vedenja, povezana z zdravjem in nekatera zdravstvena stanja pri odraslih prebivalcih Slovenije. II. Tvegana vedenja. Ljubljana: Univerza v Ljubljani, Medicinska fakulteta, Katedra za javno zdravje, 2004: 191-250.

29. Zaletel Kragelj L, Pavčič M, Maučec Zakotnik J, Koch V, Fras Z. Nezdravo prehranjevanje, povezano s prekomerno prehranjenostjo, debelostjo in diabetesom. In: Zaletel Kragelj L, Fras Z, Maučec Zakotnik J. editors. Tvegana vedenja, povezana z zdravjem in nekatera zdravstvena stanja pri odraslih prebivalcih Slovenije. II. Tvegana vedenja. Ljubljana: Univerza v Ljubljani, Medicinska fakulteta, Katedra za javno zdravje, 2004: 251-83.

30. Fabry P, Tepperman J. Meal frequency: a possible factor in human pathology. Am J Clin Nutr 1970; 23: 1059-68.

31. Parks EJ, McCrory MA. When to eat and how often? Am J Clin Nutr 2005; 81: 3-4.

32. ao G, Booth S L, Sadowski JA, Prior RL. Increases in human plasma antioxidant capacity after consumption of controlled diets high in fruit and vegetables. Am J Clin Nutr 1998; 68: 1081-7.

33. Prior RL. Fruits and vegetables in the prevention of cellular oxidative damage. Am J Clin Nutr 2003; 78(Suppl 3): S570S-8.

34. Koch V, Kostanjevec S. Pogostost uživanja živil. In: Gabrijelčič Blenkuš $\mathrm{M}$, editor. Prehrambene navade odraslih prebivalcev Slovenije iz vidika varovanja zdraja II. Ljubljana: Univerza v Ljubljani, Pedagoška fakulteta, 2009: 61-85.

35. Dauchet L, Amouyel P, Hercberg S, Dallongeville J. Fruit and vegetable consumption and risk of coronary heart disease: a meta-analysis of cohort studies. J Nutr 2006; 136: 2588-93.

36. World Health Organization. Global strategy on diet, physical activity and health. Available Oct 15, 2012 at:. http://www.who. int/dietphysicalactivity/strategy/eb11344/strategy_english_web. pdf . 
37. McAfee JA, McSorley ME, Cuskelly JG, Moss WB, Wallace MWJ, Bonham PM, Fearon MA. Red meat consumption: an overview of risks and benefits. Meat Sci 2010; 84: 1-13.

38. Bingham SA, Hughes R, Cross AJ. Effect of white versus red meat on endogenous $\mathrm{N}$-nitrosation in the human colon and further evidence of a dose response. J Nutr 2002; 132: S3522-5.

39. World Cancer Research Fund, American Institute for Cancer Research. Food, nutrition and the prevention of cancer: a global perspective. Washington, DC: American Institute for Cancer Research, 2007. Available Jan 10, 2013 at: http://www.wcrf.org/ cancer_research/cuo/recommendation.php.

40. Djousse L, Akinkuolie A O, Wu JHY, Ding EL, Gaziano JM. Fish consumption, omega 3-fatty acids and risk of hart failure: a meta-analyses. Clin Nutr 2012; 31: 846-53.

41. Apostolova GL, Thompson PM. Mapping progressive brain structural changes in early Alzheimer's disease and mild cognitive impairment. Neuropsychologia 2008; 46 (6): 1597-1612.

42. Žemva A. Kardioprotektivni učinki ribjega olja in omega-3 večkrat nenasičenih maščobnih kislin. Zdrav Vest 2004; 73: 37-9.

43. Calder PC. Long-chain fatty acids and cardiovascular disease: further evidence and insight. Nutr Res 2004; 24: 761-72.
44. British Nutrition Foundation. Nutrition science: risk of deseases. Available Dec 15, 2012 at: http://www.nutrition.org.uk/ nutritionscience/disease/hart-disease.

45. Gabrijelčič Blenkuš M. Prehrana mladostnika. In: Kostanjevec S, Torkar G, Gregorič M, Gabrijelčič Blenkuš M, editors. Zdrav življenjski slog srednješolcev: priročnik za učitelje. Ljubljana: Inštitut za varovanje zdravja Republike Slovenije, 2005: 25-34.

46. World Health Organization. Reducing salt intake in populations: report of a WHO Forum and technical meeting 5-7 October 2006. Paris, Geneva: World Health Organization, 2007.

47. Jou J, Techakehakij W. International application of sugarsweetened beverage (SSB) taxation in obesity reduction: factors that may influence policy effectiveness in country - specific contexts. Health Policy 2012; 107: 83-90.

48. Gabrijelčič Blenkuš, M. Periodičnost uživanja obrokov. In: Gabrijelčič Blenkuš $M$, editor. Prehrambene navade odraslih prebivalcev Slovenije iz vidika varovanja zdravja II. Ljubljana: Univerza v Ljubljani, Pedagoška fakulteta, 2009: 43-60.

49. World Healt Organization. Draft action plan for the prevention and control of noncommunicable diseases 2013-2020: report by the Secretariat. Available Jun 15, 2013 at: http://www.who.int/nmh/ publications/ncd_action_plan2013.pdf. 